\title{
Influence of central bank regulations on interbank competition in association with EU
}

\author{
George Abuselidze ${ }^{1, *}$, and Malvina Kizinidze ${ }^{1}$ \\ ${ }^{1}$ Batumi Shota Rustaveli State University, 6010, 35, Ninoshvili str., Batumi, Georgia
}

\begin{abstract}
In the work it is focused on the determining factor of interbank competition, the level of competitiveness between banks and legislative regulations. They are also studied in the banking system of Baltic states. The purpose of the work is to identify existence of interbank competition, its causing reasons determining and reviewing regulatory ways, as well as identifying the impacts of National Bank regulations and developing recommendations. During the survey, in-depth analysis of the issue, to identify the existing problems and determine the ways of its solution, to comprehend the comparative analysis, conclusions and recommendations, was studied Georgian and EU (including the Baltic countries) public information about commercial banks, regulation documents, internet sources, which are characterized by a high degree of reliability. At the final stage, it was evaluated the existence of competition in the Georgian banking system and determined its stimulating factors.
\end{abstract}

\section{Introduction}

The banking system of Georgia has been functioning for a long time and is developing in market conditions. The normal functioning of the banking system requires competition and development of the market. Banking system in Georgia requires the regulation of the National Bank, which will ensure fair and fair competition conditions that will ensure the effectiveness of commercial banks' performance. The main precondition for sustainable functioning of the banking market is the existence of interbank competition, which is the topical issue of today's banking system and is developing at a low level. The goal of the research is to determine the existence of the interbank competition, the level of competition in today's conditions. The research also aims at reviewing regulation of competition and developing recommendations. Identify the impacts of the National Bank regulations on the business sector, determine the problem and determine the ways of its solution. The object of research is the commercial banks of the Georgian banking market. The subject of research is to determine the existence of competition on the banking market of Georgia, to determine the level of competition, its regulation by the National Bank of Georgia, to identify the influence of new regulations business entities.

* Corresponding author: george.abuselidze@bsu.edu.ge 


\section{Problem Formulation and Methodology}

\subsection{Literature Review}

Research methodology and information base are based on Georgian and foreign economic documents and legislative acts, scientific papers, annual reports of reliable sources. Among the last economic reforms implemented for overcoming of the world financial and economic recessions the special emphasis is made to macroeconomic stabilization [1] and socioeconomic strengthening of the country is recognized one of the imperatives, what cannot be well-reasoned without monetary policy. Operation of Monetary policy play the important role in promotion of economic activities and growth of production volume, further socioeconomic development of the country [2]. The monetary policy pursued by the central bank serves two interrelated purposes: to encourage financial system stability and activity of the weakened economic. One of the important factors in achieving these goals is the existence of the inter-bank competition. However, Marcus [17], Keely [14], Carletti and Hatmann [13] consider that competition leads to financial system instability, while Shaeck and Cihak , Boyd [12] pursue that empirical evidence suggests that the competitive banking market is less inclined to bankruptcy and banking crisis. We hold to this point of view and, together with other scientists, assume that competition is an important factor for achieving sustainability. Consequently, it is undoubtedly relevant to carry research in this area, especially in the case of Georgia, Post-Soviet country for developing recommendations based on the experience of EU countries.

Shaeck has found a positive correlation between banking stability and banking competition by applying the PR method. Shaeck, Cihak and Wolfe have studied 2600 European Banks and revealed that Capital Ratio was higher in a competitive environment.

\subsection{Ways to Improve Banking Competition Formation}

\subsubsection{Condition of Interbank Competition and its Formation in the Banking Sector of Georgia}

Competition is characteristic for all markets, including the bank market. It is regulated by the Law of Georgia on Competition. Banking competition is a type of the market competition. It is characterized by certain specific signs that distinguish banking competition from competition of other markets.

Competition is limited in Georgian banking market. Due to the fact that 15 commercial banks and up to 60 micro finance organizations, but in reality just two banks are in the lead. This means that competition is at very low level. The main competitors of the banking market are Bank of Georgia and TBC Bank, which is determined by the share of these banks in the banking market. TBC Bank owns 37\% of the bank market and Bank of Georgia has $35 \%$.

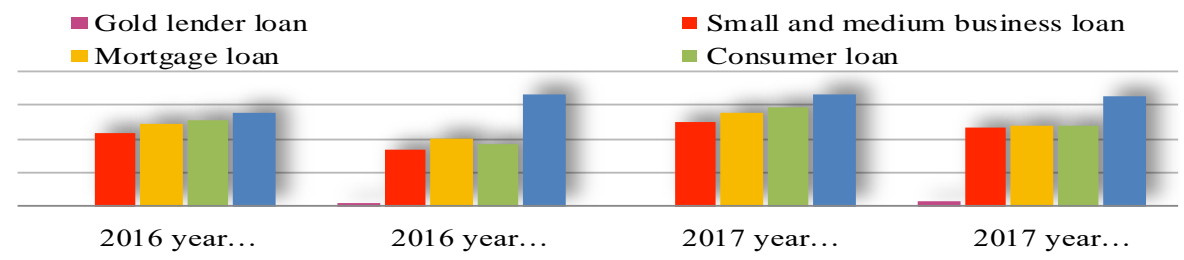

Fig.1. The Capacity of Loans Issued by TBC Bank and the Bank of Georgia in Source: drawn up by the authors of the $\mathrm{c} / \mathrm{b}$ data [18] 
In recent years TBC Bank has purchased Bank Republic and Constanta as well as Progress Bank's credit portfolio, which led to doubling of TBC Bank's assets. For three years, TBC Bank's assets increased from GEL 6.9 billion to GEL 12.9 billion. Bank of Georgia picked up the Privat Bank and purchased the Micro and Small Loan Portfolio of ProCredit Bank. Accordingly, Bank of Georgia's assets grew from GEL 9 billion to GEL 12.6 billion [19].

The capacity of loans given by TBC Bank is much more than in Bank of Georgia. TBC Bank has given more than $11 \%$ corporate loan in comparison with the Bank of Georgia in 2017 , but in 2016, TBC has been backed by almost $20 \%$ (19.9\%).

The next product is deposits. Now we compare these two competing banks with their

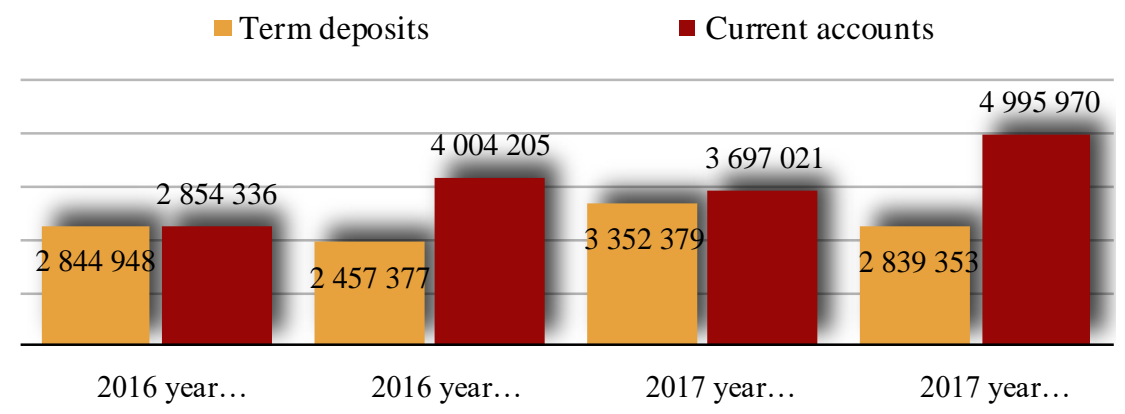

liabilities towards depositors (Fig. 2)

Fig. 2. Liabilities of TBC Bank and Bank of Georgia Before Costumers in 2016-2017 Source: drawn up by the authors of the $\mathrm{c} / \mathrm{b}$ data [18]

According to the Figure 2, TBC Bank is still in the standpoint of depositors' liabilities. Bank of Georgia is in the first place by deposits that can be caused by the acceptable terms of the product, the interest rate. The large capacity of accounts in TBC Bank is due to the fact that cash withdrawals from TBC Bank's cards are free from ATM. It should also be noted that TBC Bank is already on the market of Azerbaijan and Uzbekistan, which in itself means increasing the number of customers and their accounts.

According to the data of 2016, we will look at the Bank's 5th Assets, Loans, Capital and Net Profits (Fig. 3-5).

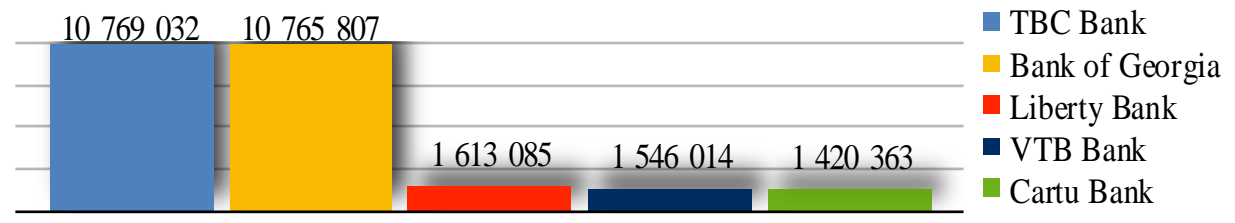

Fig. 3. Five of the Banks According to the Assets

Source: drawn up by the authors of the $\mathrm{c} / \mathrm{b}$ data [18]

According to the capacity of assets, TBC Bank is followed by Bank of Georgia with $0,029 \%$. The reason for the changes in the assets of competing banks is the changes such as the reunification of banks or the structural reorganization. TBC Bank's and Bank of Georgia's leading is caused by purchase of certain banks, namely TBC Bank's accession to Constanta Bank and Republic Bank, as well as the Progress Bank's credit portfolio, and 
Bank of Georgia purchased the Privat Bank and the Micro, Small and Medium Loan Portfolio of ProCredit Bank.

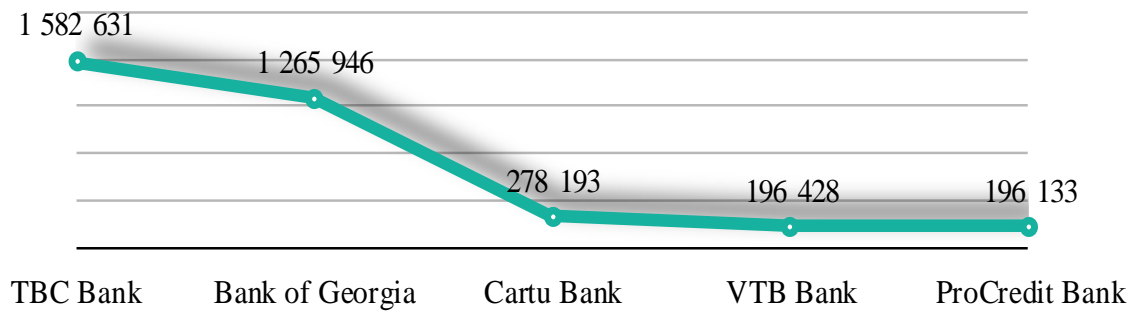

Fig. 4. Five of the Banks According to the Amount of Capital Source: drawn up by the authors of the $\mathrm{c} / \mathrm{b}$ data [18]

The amount of capital of TBC Bank and Bank of Georgia is caused by the fact that I mentioned above, by merging banks. Bank of Georgia is behind TBC Bank's capital amount by $25 \%$.

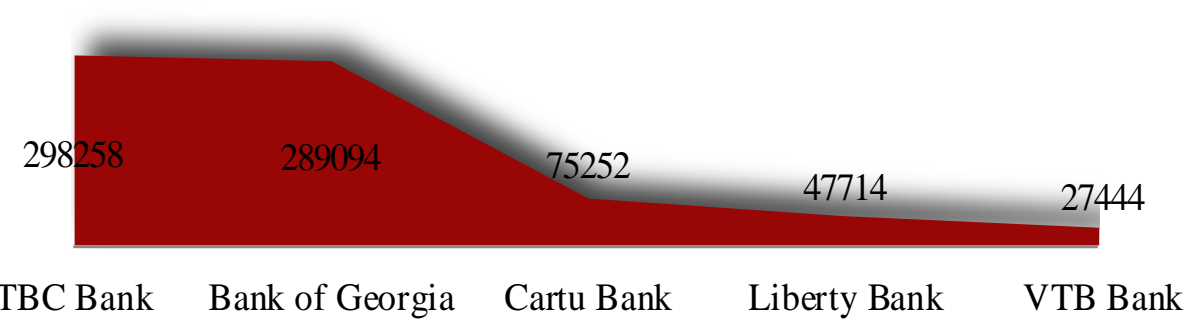

Fig. 5. Five of the Banks According to the Earned Net Profit Source: drawn up by the authors of the $\mathrm{c} / \mathrm{b}$ data [18]

According to the earned net profits, as other criteria, two banks TBC and Bank of Georgia are leading, and first place has the TBC Bank. Earned net profit mainly is determined not only lending, issuing loans, but also plays an important role increasing noninterest expenses, losses from possible losses of assets and also increasing outdated loans.

These figures show that competition is very low and the main part of the market is holding two banks, such as Bank of Georgia and TBC Bank. The existence of low competition means that the market is less efficient.

Competitiveness on the banking market is determined by the interest rate on attracted deposits and issued loans. The interest rate plays a major role in the number of clients. The interest rate for consumer loan starts in Tera Bank from 11.90\%, while the Bank of Georgia has a minimum of $9 \%$. In addition, checking credit information is necessary to make a loan and in Tera bank you must pay 10 GEL, but in Bank of Georgia it is free [3].

The 6th figure shows the difference between consumer and mortgage loans in the two banks. Bank of Georgia offers the best conditions with $1.9 \%$ on consumer loans. In addition, the minimum amount of loan for Tera Bank is GEL 1000, while in the Bank of Georgia this amount is 200 GEL. For customers it is better and acceptable to make a minimum of 200 GEL loan and better for the bank, as this condition will provide a lot more loan. 


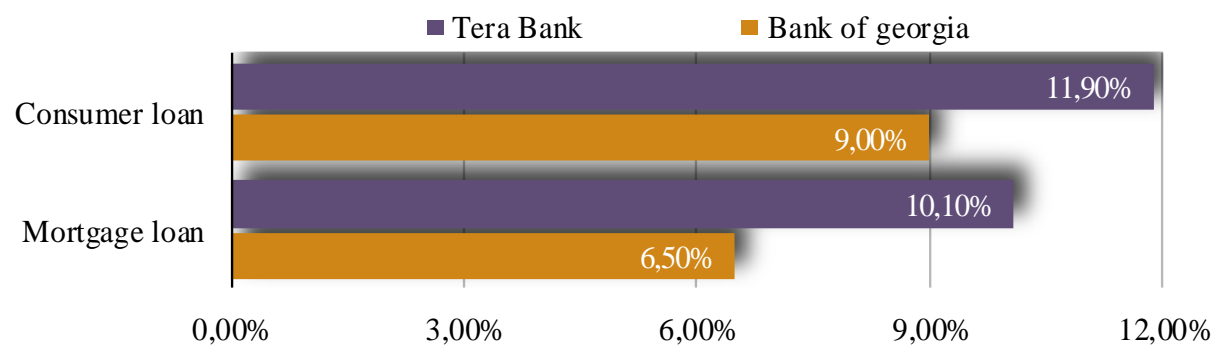

Fig. 6. Interest Rates on Consumer and Mortgage Loans

Different interest rates are not only on loans, as well as on deposits. For instance, Liberty Bank has a fixed deposit of 24 months at $10.15 \%$ when TBC bank offers $10.20 \%$ on a 2-year deposit. In this case the difference is not great, however, the difference between interest rates on the collecting deposit is $1.70 \%$.

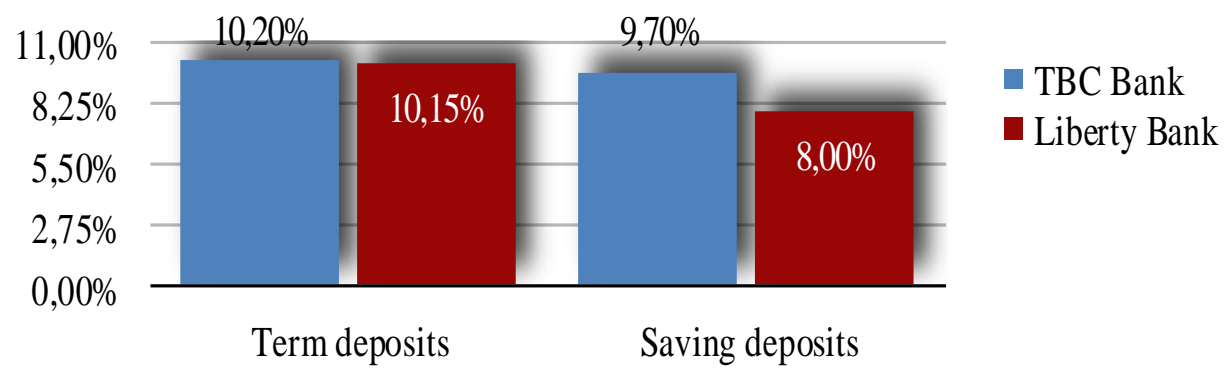

Fig. 7. Interest Rates on Deposits

Source: drawn up by the authors of the commercial banks data [15]

TBC Bank also offers to withdraw money from the card without any fee, which is one of the acceptable conditions for the customer.

Apart from the interest rates on loans or deposits, on the competitiveness big influence has number of the Bank's branches, ATMs, terminals and PAY machines, which are available for access. The fact that costumers service bank is available everywhere is very important for the population (Fig. 8).

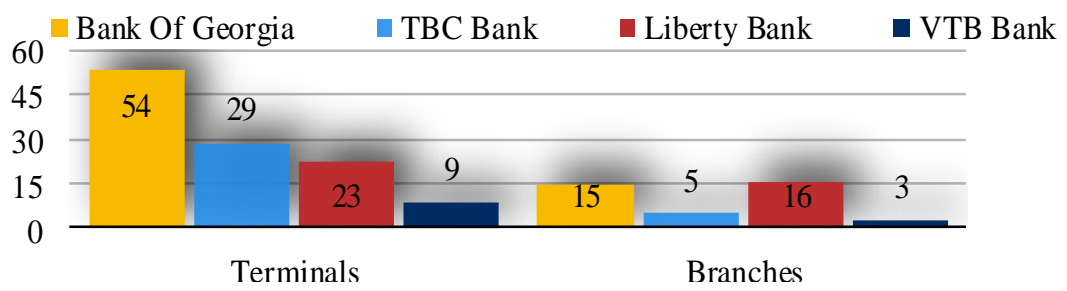

Fig. 8. ATMs and Banks' Branches in Batumi

Source: drawn up by the authors of the commercial banks data $[3,16]$

The Bank of Georgia has the largest number of ATMs. The data shows that Liberty Bank has more branches than other banks, it is because you can get the pension only in Liberty Bank. In addition, the population employed in the state agency is mainly paid in 
Liberty Bank. In my opinion, these two factors lead to the capacity of Liberty Bank branches and ATMs.

One of the factors determining banking competition is the trust of the consumers towards commercial banks. The bank lends confidence in consumers and investors through the publication of financial results by the amount of net profits earned by the capacity of capital or assets. The leadership of the two banks in the banking sector, the trust of their customers, is also due to the fact that they have a certain amount of shares on the London Stock Exchange. TBC Bank also entered into the Uzbek market with 55\% of the PAYME shares of the Payment Platform; in a result it increased $70 \%$ of consumers by 2018 . TBC Bank's subsidiary "TBC Credit" joined "Nikoil Bank" and owns 10 percent of Nikoil shares. While the Bank of Georgia has subsidiaries in Hungary, Belarus, Israel and Great Britain. The above facts, I think, play an important role in obtaining consumer confidence in commercial banks. Actually there is competition, but developed at a low level. On the one hand, the low level of competition has led to the fact that in recent years, the two "giant" banks have already bought the bank's capital, assets and credit portfolio. In order to further develop competition, the National Bank shall introduce regulations that prohibit "swallowing" banks operating in the market.

\subsubsection{Foreign Banking Competition and its Formation}

Baltic countries: Latvia, Lithuania and Estonia represent the Council of Europe and EU Member States. These countries are classified by the World Bank as high-income, economically strong countries. Consider banking competition in the Baltic States.

There are 6 banks operating in Lithuania [9], including Swedbank, Luminor ab, Seb bank, Ab Siauliu bank, Citadele bank ab and Uab Medicinos bank. In these banks.

According to the assets and income of Lithuania (Fig.9-10) are three strong banks: Swedbank, Seb bank and Luminor Ab bank. However, according to data from 2017, the Luminor Ab Bank received $€ 84.89$ million in revenues, at the end of the year 13.01 million euros. The Luminor AB bank was formed by the merger of Nordea Bank and DNB Bank in 2017, this bank is in the third place with assets.

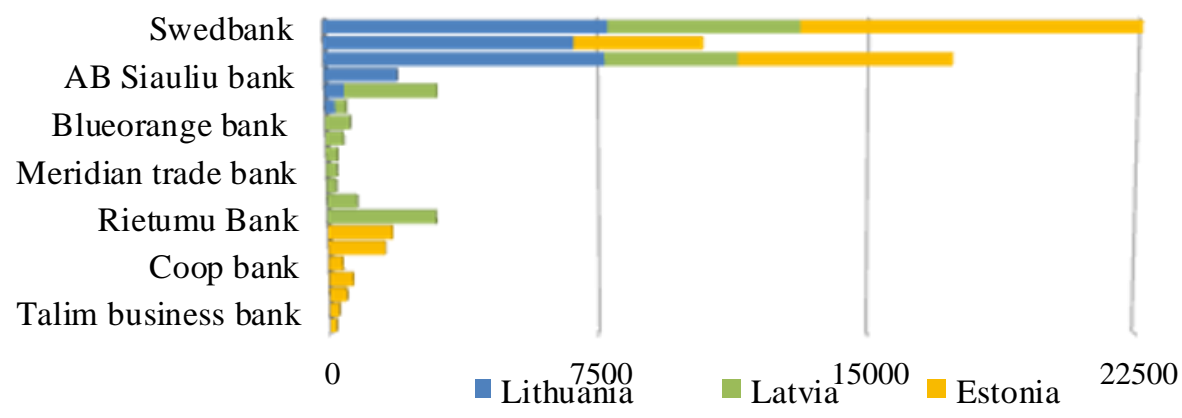

Fig. 9. The Assets in Lithuanian, Latvian and Estonian Banks (in millions) Source: drawn up by the authors of the $\mathrm{c} / \mathrm{b}$ data $[10,11]$

In contrast to Lithuania, 10 commercial banks operate in Latvia. Swedbank, seb bank and citadele bank are also included in the list of Latvian banks. According to the current assets, the earnings received in Sweden are: Swedbank, Seb bank and Rietumu Bank. 
Three banks have received losses in 2017, including Norvik Bank, with a loss of 10.52 million euros, despite that the capacity of earnings and assets being included in the five banks of the Latvian banks. Another bank, which received damage in Latvia in 2017, is the Meridian trade bank with $€ 235$ million. This bank is in the second place from the bottom of the assets and in the last place by earn income.

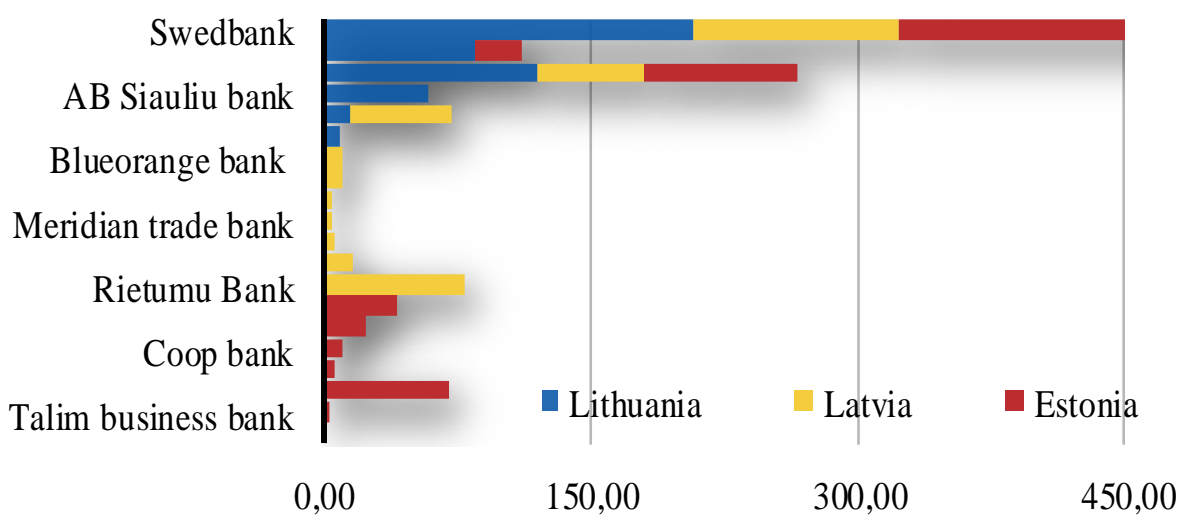

Fig. 10. Lithuanian, Latvian and Estonian Banks' Income

Source: drawn up by the authors of the $\mathrm{c} / \mathrm{b}$ data $[10,11]$

In the Baltic countries are also listed Estonia, where there are also 10 commercial banks, including Swedbank and Seb bank. Apart from these banks, in the list of Estonian commercial banks is: Luminor Bank, LHV Bank, Danske Bank a/s branch, Coop Bank, OP corporate bank, Bigbank as, Tlm business bank, Handelsbanken. Information about the income and assets earned by the banks mentioned above are the Figures 9 and 10.

Depending on the figures, two banks of Estonia are leaders in banking system: Swedbank and Seb bank. These two banks have a great advantage in all three Baltic countries, both in capacity of capital and in terms of income earnings, which are due to the quality of bank products, which are acceptable for consumers.

In the Baltic countries: Latvia, Lithuania and Estonia are not many commercial banks, but two leaders are the Swedbank and Seb bank. These two banks are strong in all three countries, as well as in the capacity of assets as well as income.

\section{Problem Solution}

\subsection{Influence of National Bank Regulations on Interbank Competition}

\subsubsection{Influence of National Bank Regulations on Georgian Banking System}

The low level of competition on the Georgian bank market is due to the incorrect approaches of the National Bank. However, if we look at 2018 regulations which came into force from 7 May and meant consumer loans and installment with only proven income, it could be said that the regulation affected the development of the competition positively. Installment and consumer loan from May 7, 2018 has been made possible if the customer has the sum of the salary accrued for the last 6 months. The number of loans and installment have been decreased due to the fact that a large portion of the population is unable to install credit for various reasons. One of the reasons is that in the country the part 
of the enterprise does not employ the employee, the salary is paid on the hand and does not pay the income taxes.

According to the data of 2018, the capacity of installment decreased by 2017 , which is the result of the above mentioned regulations. As for the capacity of consumer loans, there is a slight increase in 2018 compared to the previous year, while mortgage loans increased by 1517 million. There is also increased small and medium business loans.

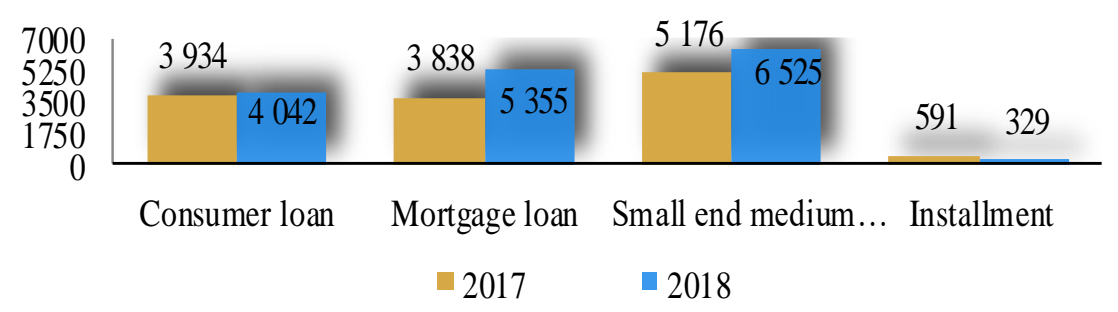

Fig. 11. Loans Issued in 2017-2018 (in millions)

Source: National Bank of Georgia [19]

Figure 11 shows that the installment is reduced by 262 million. The reason is the 2018 regulations. As for the consumer loan, its capacity is increased but with a little bit of 158 million. While the volume of mortgage loans and small and medium business loans has increased. Mortgages can be made both on wages and on business income. It can be said that increasing the number of mortgage loan is directly related to the increasing of the business loans.

In accordance with the regulations set out in January 1, 2019, micro finance organizations and banks are obliged to estimate the borrower's solvency. This regulation provides for the loan by the borrower's income. The National Bank defines limits according to the creditor should make a monthly payment for consumers for loans, this is PTI coefficient. If the monthly income of the borrower is less than 1000 GEL, the PTI coefficient may be considered a maximum of $25 \%$ of its monthly income. Table 1 of the PTI coefficient set by the National Bank of Georgia.

Table 1: Maximum Payment to Income Ratios

\begin{tabular}{|c|c|c|}
\hline Monthly net income & Hedged borrowers & Non hedged borrowers \\
\hline$<1000$ & $25 \%-35 \%$ & $20 \%-25 \%$ \\
\hline$\geq 1000-2000<$ & $35 \%-45 \%$ & $20 \%-25 \%$ \\
\hline$\geq 2000-4000<$ & $45 \%-55 \%$ & $25 \%-30 \%$ \\
\hline$\geq 4000$ & $50 \%-60 \%$ & $30 \%-35 \%$ \\
\hline
\end{tabular}

Source: National Bank of Georgia [20].

Regulations of 2019 also considers changes on setting the chains on loans. If credit officer sets someone as chain on costumers loan, he must calculate his monthly income. Chains on the credit can be made only within the amount of money that chain earn income every month [20]. 
The amendments were also made on loan support. If the loan is secured by real estate, it should be taken into consideration, that the amount of loan issued in GEL should be a maximum $85 \%$ of the real estate market value, and the amount of loan issued in foreign currency - 70\% (Table 2).

Table 2: Maximum Loan to Value Ratios

\begin{tabular}{|c|c|}
\hline $\begin{array}{c}\text { Maximum loan to value ratio (LTV) } \\
\text { for GEL loans }\end{array}$ & $85 \%$ \\
\hline $\begin{array}{c}\text { Maximum loan to value ratio (LTV) } \\
\text { for foreign currency loans }\end{array}$ & $70 \%$ \\
\hline
\end{tabular}

Source: National Bank of Georgia [20].

After 2018-2019 regulations, the capacity of instalments decreased, tightened making the loan to individuals, which negatively affected to the hardware stores. In particular, the hardware store Beko has decreased sales by 50\%. According to "Beko"s general director, prices decreased by $10 \%$ due to a reduction in the realization of equipment. In addition, 4 branches of "Techno Boom" was closed: in Telavi, Lanchkhuti, Zugdidi and Kobuleti, because of $50 \%$ due to decrease of realization $[19,20]$. These regulations were followed by the merging of certain hardware stores, such as Aray-smile.

The above problems are mainly caused by various reasons. One of the reasons is the "hidden" revenue. The enterprises are not accounting incomes in order to pay less money in the budget. If all this gets better, making the loan will be easy. An instant instalments will also increase. So the reduction in instalment has become a reason for reducing trade in stores.

\subsubsection{Foreign Practice of Bank Regulation}

In the Baltic countries is low level of competition like in Georgia, based on that in all three countries from 6 and 10 commercial banks are leading Swedbank and Seb bank, both in terms of assets as well as income.

The main regulations of the National Bank of Lithuania, which affect banking system, start from 2011. According to the 2011 Regulations of the National Bank of Lithuania [4, 7, 8 ] the capacity of mortgage loan secured by an asset cannot exceed $85 \%$ of this asset's market value. The mentioned regulations came into force in Georgia from January 1, 2019. Under Lithuania's regulations, a loan taken for the purchase of an agricultural land cannot exceed $40 \%$ of the market value of the purchased plot. These regulations came into force from 1 November 2011.

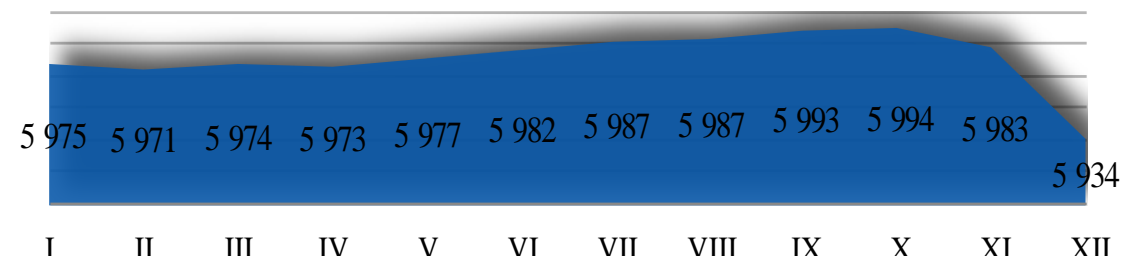

Fig. 12. Mortgages Issued in 2011 by Months (in millions)

Source: loans to residents 2011-2018 
The 12th figure shows that mortgage loans have been reduced since the November 2011 regulations. Compared to November, the capacity of mortgage loans in December decreased by 49.4 millions.

As regulations of March 31, 2013, the 60-day withdrawal of consumer loans amounted to $30 \%$ of loans issued. The main reason for this is the poor assessment of the solvency of the borrowers. The credit organizations have found out that they often don't check the client's financial condition. Another problem is advertising, which provides information to the society incomplete. According to the advertisement, the credit is a way to solve the problem, and in fact the loan is the start of the problem.

According to regulations of July 1, 2013, advertising companies are obliged to fully advertise the terms and conditions of the loan. According to the law, advertisements containing vague and incomplete information are prohibited. Also creditors are obliged to verify the financial condition of the borrower and its solvency [5].

The regulation of 2013 also envisages amendments to pay penalties under which the penalty is charged as a borrower and credit officer in case of overdue. The fine on the first overdue is $5 \%$ of the principal amount of the loan and $10 \%$ of the subsequent payments.

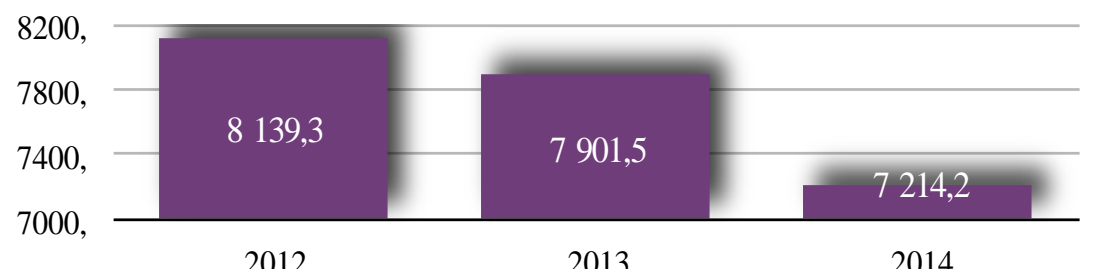

Fig. 13. Consumer Loans (mln) Issued in 2012-2014

Source: Loans to residents 2011-2018

Figure 13 shows the capacity of consumer loans issued in 2012-2014. Consumer loans in 2012 were 8139.3 million, down 237.8 million in 2013, and in 2014 it was only 7214.2 million consumer loan. The diagram shows that the capacity of consumer loans decreased sharply after 2013 regulations

The maximum term for mortgage loans up to 2015 was 40 years. The deadline for the 2015 regulations has been reduced by 30 years, and the maximum term of mortgage loan repayment in Georgia is 15 years, 2 times less than in the Baltic States. According to the statement of National Bank of Lithuania, the mortgage loan repayment term has been reduced because of the longer term loan, the borrower has to pay more percentage. In a result the reduction of the term of the loan increased about $1 / 10$, and the number of payable percentages decreased by almost $40 \%$ [6].

When credit companies are lending to real estate, according to the regulations, the interest rate of the loan must be less than $5 \%$ on the standard percentage, and the borrower's monthly fee shall not exceed $50 \%$ of the monthly income.

Fig. 14. Mortgages Issued in 2014-2016 (in millions)

Source: Loans to residents 2011-2018 
According to the National Bank data, the capacity of mortgage loans issued in 20142016 is given in Figure 14, from which the capacity of mortgage loans increases from year to year. Compared to the previous year in 2016 , capacity of issued loans increased in $6 \%$, which in my view is caused by the loss of $5 \%$ on the loan made by real estate.

Until 2017, it was not possible to cover the loan or refinance it, and after July 1, 2017, it was possible. In addition, these regulations also provide an opportunity to reduce the interest rate. During the financial difficulties of the borrower, he / she will be able to enjoy a credit holidays. Along with all this, the penalty imposed on the overdue has been changed and it will be calculated on a daily overdue day by $0.05 \%$ of the principal loan amount. With regulations of July 1, 2017, when you are making a mortgage loan, it is required a primary instalment $15 \%$ of the requested loan amount to pay [8].

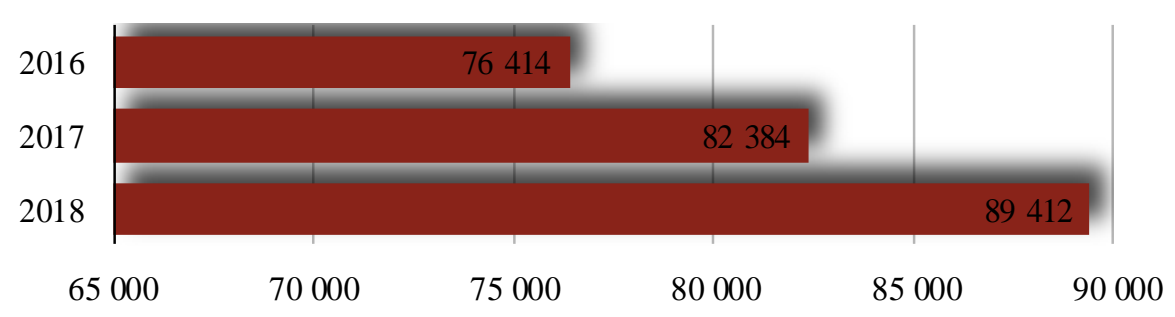

Fig. 15. Mortgages Issued in 2016-2018 (in millions)

Source: Loans to residents 2011-2018

Figure 15 shows that despite the changes in mortgage loan issuance, their capacity is still rising, which caused by decreasing interest rates. According to the data of 2017, the capacity of mortgage loans increased by 5969.9 million in comparison with the previous year, and by 2018 the amount was 7028.5 million.

Making the loan in Latvia was complicated after the 2008 economic crisis. The banks were demanding proof of income to be able to assess the borrower's ability to pay. This regulation in Georgia came into effect from May 7, 2018. At this time in Latvia, micro finance organizations emerge on the market, which are borrowing to customers without documenting income.

The law on consumer rights protection determines that any outflow of the borrower is related to the percentage of the credit, which is often beyond the amount of the loan. The regulations on 1 January 2016 banned the fact that the interest accrued on the loan exceeded the loan amount. For example, if a borrower has loaned 200 euros, the interest accrued on it cannot be more than 200 euros, so a creditor can take a maximum of 400 euros.

According to the law, the penalty imposed on the loan may not exceed $10 \%$ of the loan amount. Until now, it will be postponed in the country like this: If the borrower was not able to repay the loan on time, the bank offered to pay 30 euros and cover the loan for one year. In fact, the borrower paid double and more money, which was to be paid.

Also, 2016 regulations prohibit quick loan from 23: 00 to 07: 00. Depending on the statistics in these hours are lending young people, who are depended on gambling games.

\section{Conclusion}

Our research allows us to draw the following conclusions:

1. Competition on the banking market in Georgia has been developed at very low level, which confirms the leadership of the two banks on the banking market. These include Bank of Georgia and TBC Bank. This is due to various reasons, primarily through TBC 
and Bank of Georgia purchasing of other banks' assets, equity or credit portfolio. As well as the banking products prices, trusts to banks. One of the challenging factors is a set of banks' banks, ATMs and PAY machines.

2. Some changes were made to the banking market after regulating the 2018-2019 regulations on NBG, limiting consumer loans and installment loans, also when the mortgage loan is issued, it must be calculated the Borrowing Coefficient and the PTI Coefficient, which is set by the National Bank resulted in reducing loans. This effected a strong influence on the business sector, in particular the closure of certain equipment stores and the reduction of prices to increase realization.

3. Competition in the Baltic countries, as well as competition in Georgia, is at a low level. Since all three countries are leading two commercial banks, Swed Bank and Seb Bank, both in terms of assets as well as income.

4. In the Baltic countries and in Georgia banking products are very different from each other. While Georgian banks account for $10.20 \%$ of GEL deposits, interest rate in Lithuania, Latvia and Estonia varies between $0.01 \%-0.05 \%$. For example, if the maximum term of mortgage loan in Georgia is 15 years, the maximum term of the Baltic is 30 years.

\section{References}

1. G. Abuselidze Journal of Business and Economics Review, 3, 1 (2018).

2. G. Abuselidze Academy of Strategic Management Journal, 18, 4 (2019).

3. Bank of Georgia. ATMs and branches, https://bankofgeorgia.ge/retail/ge/branches-and-atms

4. Bank of Lithuania. Approved regulations for responsible lending (2011). https://www.lb.lt/en/news/the-bank-of-lithuania-approved-regulations-for-responsiblelending

5. Bank of Lithuania. Proposes to tighten requirements for consumer credit drawers by way of a law (2013). https://www.lb.lt/en/news/the-bank-of-lithuania-proposes-totighten-requirements-for-consumer-credit-drawers-by-way-of-a-law

6. Bank of Lithuania. Proposal to more responsibly assess the risk of housing loan lenders and reduce the possibility of over-indebtedness, (2015). https://www.lb.lt/en/news/proposal-to-more-responsibly-assess-the-risk-of-housingloan-lenders-and-reduce-the-possibility-of-over-indebtedness

7. Bank of Lithuania. Responsible lending regulations: strengthening the resilience of borrowers to adverse interest changes. (2015). https://www.lb.lt/en/news/responsiblelending-regulations-strengthening-the-resilience-of-borrowers-to-adverse-interestchanges

8. Bank of Lithuania. Conditions provided for market participants to prepare for new mortgage credit market regulation, to come into force as of the middle of this year, (2017). https://www.lb.lt/en/news/conditions-provided-for-market-participants-toprepare-for-new-mortgage-credit-market-regulation-to-come-into-force-as-of-themiddle-of-this-year.

9. Bank of Lithuania. Review of the survey of risks to Lithuania's financial system (2018).

https://www.lb.lt/uploads/publications/docs/21184_497e2193bdc56a6ac7f64105fb46b 39a.pdf. 
10. Become a World-Class Financial Analyst. Overview of Estonia's leading financial institutions

https://corporatefinanceinstitute.com/resources/careers/companies/top-banks-inestonia/

11. Become a World-Class Financial Analyst. Overview of Latvia's leading financial institutions

https:/corporatefinanceinstitute.com/resources/careers/companies/top-banks-in-latvia/

12. J.H. Boyd, G. De Nicolo The Journal of finance, 60, 3 (2005). https://doi.org/10.1111/j.1540-6261.2005.00763.x

13. F. Carletti, P. Hartmann Monetary History, Exchange Rates and Financial Markets: Essays in Honour of Charles Goodhart, (2003)

14. M. Keeley The American Economic Review, 80, 5 (1990)

15. Liberty Bank. Term deposits (2019), https://www.libertybank.ge/ka/produqtebi/chemtvis/anabrebi-da-sertipikatebi/vadiani

16. Liberty Bank. ATMs and branches (2019), https://www.libertybank.ge/ka/chvenshesakheb/kompaniis-shesakheb/chveni-qseli

17. A.J. Marcus Journal of Banking \& Finance, 8, 4 (1984), DOI: 10.1016/S03784266(84)80046-1

18. National bank of Georgia. Financial stability 2006-2017 years datas (2018), https://www.nbg.gov.ge/index.php? $\mathrm{m}=404$

19. National Bank of Georgia. Annual report 2018 (2019). https://www.nbg.gov.ge/uploads/publications/annualreport/2019/annual_2018.pdf

20. National Bank of Georgia. New regulations (2019). https://www.nbg.gov.ge/index.php?m=340\&newsid=3545 